\title{
Spirolactone iridoids might be responsible for the antileishmanial activity of a Peruvian traditional remedy made with Himatanthus sucuuba (Apocynaceae)
}

\author{
D. Castillo ${ }^{\text {a }}$, J. Arevalo ${ }^{\text {a,e }}$, F. Herrera ${ }^{\text {a }}$, C. Ruiz ${ }^{b}$, R. Rojas ${ }^{c}$, E. Rengifo ${ }^{d}$, \\ A. Vaisberg ${ }^{\mathrm{e}}$, O. Lock ${ }^{\mathrm{b}}$, J.-L. Lemesre ${ }^{\mathrm{f}}$, H. Gornitzka ${ }^{\mathrm{g}}$, M. Sauvain ${ }^{\mathrm{h}, *}$ \\ a Instituto de Medicina Tropical “Alexander von Humboldt”, Universidad Peruana Cayetano Heredia (UPCH), Av. Honorio Delgado 430, SMP, Lima, Peru \\ ${ }^{\mathrm{b}}$ Departamento de Química, Pontificia Universidad Católica del Peru, Av. Universitaria cuadra 18 s/n, San Miguel, Lima, Peru \\ ${ }^{\mathrm{c}}$ Departamento de Ciencias Farmacéuticas, Facultad de Ciencias y Filosofía, UPCH, Lima, Peru \\ d Instituto de Investigaciones de la Amazonía Peruana, Av. Abelardo Quiñónez km 2.5, Iquitos, Peru \\ e Laboratorios de Investigación y Desarrollo, Facultad de Ciencias y Filosofía, UPCH, Lima, Peru \\ ${ }^{\mathrm{f}}$ UR 008 IRD, BP 64501, 34394 Montpellier Cedex 5, France \\ g Laboratoire d'Hétérochimie Fondamentale et Appliquée (UMR 5069), Université Paul Sabatier, 118 route de Narbonne, 31062 Toulouse Cedex, France \\ ${ }^{\mathrm{h}}$ UMR 152 IRD-Université de Toulouse III, Misión IRD, Casilla 18, 1209 Lima 18, Peru
}

Received 16 December 2006; received in revised form 12 March 2007; accepted 18 March 2007

Available online 24 March 2007

\begin{abstract}
Extracts of seven medicinal plants used specifically against cutaneous leishmaniasis in the Madre de Dios region of Peru were evaluated in vitro against promastigote and axenic amastigote forms of Leishmania amazonensis. One of them showed interesting leishmanicidal activities ( $\mathrm{IC}_{50}=5 \mu \mathrm{g} / \mathrm{ml}$ in amastigotes). Bio-guided isolation of the stem bark's ethanol extract of Himatanthus sucuuba (Spruce ex Müll. Arg.) Woodson (Apocynaceae) afforded the spirolactone iridoids isoplumericin and plumericin. The latter showed a reduction of macrophage infection similar to that of the reference drug Amphotericin $\mathrm{B}\left(\mathrm{IC}_{50}=0.9\right.$ and $1 \mu \mathrm{M}$, respectively). These findings validate the traditional use of Himatanthus sucuuba in the treatment of cutaneous leishmaniasis (Uta) in Peru.
\end{abstract}

(c) 2007 Elsevier Ireland Ltd. All rights reserved.

Keywords: Leishmania amazonensis; Peru; Himatanthus sucuuba; Plumericin; Ethnomedicine; Axenic amastigotes

American tegumentary leishmaniasis (ATL) is an endemic parasitic protozoal disease in most countries of Latin America that can present itself either as cutaneous (CL) or as mucosal leishmaniasis (ML) (Walton, 1987). It is a major public health problem in Peru where the endemic range covers $74 \%$ $\left(951.820 \mathrm{~km}^{2}\right)$ of the country. The endemic distribution pattern of cutaneous and mucosal leishmaniasis is found throughout the Andean and inter-Andean valleys in its cutaneous form, and in the tropical rain forest (low jungle and high jungle) in its mucosal form (Lucas et al., 1998). Antimonials and amphotericin B are currently used as standard drugs. However, they are associated with toxic side effects and have a restricted therapeutic spectrum

\footnotetext{
* Corresponding author. Tel.: +51 148117 94; fax: +51 14413223.

E-mail address: michel.sauvain@ird.fr (M. Sauvain).
}

for all clinical forms of leishmaniasis (Davis et al., 2004). In this context, the discovery of new active compounds with antileishmanial potential remains essential for the control and prevention of leishmaniasis. Contrary to other diseases, leishmaniasis is properly identified as a disease by the natives of the Amazonian forest (Dedet et al., 1989). This justifies the search for new leads based on ethnomedicine. Few Latin American plants have been reported as useful for the treatment of leishmaniasis. Studies focusing on herbal remedies for this disease were carried out in French Guiana (Sauvain et al., 1993), in Bolivia (Fournet et al., 1994), in Colombia (Weniger et al., 2001), in Panama and Mexico (Camacho et al., 2003), in Brazil (Muzitano et al., 2006), and in Peru (Kvist et al., 2006). Literature dealing with leishmanicidal activity in natural products from the mid-1980s to late 2001 is concentrated in three published reviews (ChanBacab and Peña-Rodriguez, 2001; de Carvalho and Ferreira, 
2001; Rocha et al., 2005). The present work investigates plants used against leishmaniasis by people of the Peruvian Amazon region to purify very active compounds against Leishmania parasites.

\section{Materials and methods}

\subsection{Collection of plants and ethnomedical information}

The field work was carried out in the Madre de Dios department on the road between the city of Puerto Maldonado and the village of Yanapari. Health promoters were contacted and interviewed. The questions concerned the occurrence of leishmaniasis in the local area with a focus on most recent cases. Patients who were confirmed to have recently suffered from cutaneous leishmaniasis were contacted and asked about the treatment they had received. If the patient had used medicinal plants either to cure or alleviate symptoms of leishmaniasis, an ethnobotanical field work was carried on. Plants were systematically collected and their respective uses recorded with the aid of the informant who had given his formal agreement to the study.

\subsection{Vouchers in herbarium}

Voucher specimen was deposited at the Herbarium of Universidad Nacional de la Amazonia Peruana in Iquitos. A first assessment of the identity of the plants was conducted by the ethnobotanist of the team with the help of specialists of the plant family of interest.

\subsection{Preparation of extracts}

Fifty grams of air-dried powdered plant material was extracted during 10 days at room temperature with $500 \mathrm{ml}$ of $95 \%$ ethanol. After filtration, the solvent was evaporated to dryness under reduced pressure at a temperature lower than $40^{\circ} \mathrm{C}$. For the bioassay, the extracts were resuspended in DMSO at a concentration of $10 \mathrm{mg} / \mathrm{ml}$.

\subsection{Bioassay-guided isolation and structure elucidation of active principles}

Dried powdered bark (700 g) of Himatanthus sucuuba was extracted by maceration with $95 \%$ ethanol. The solvent was then evaporated to dryness under reduced pressure at temperature lower than $40^{\circ} \mathrm{C}$ to obtain the crude extract $(20.8 \mathrm{~g})$. Part $(19 \mathrm{~g})$ of this ethanol extract was partitioned with solvents of different polarities. The yields of the obtained fractions were $3.3,0.93,4.7$ and $8.7 \mathrm{~g}$ for the solvents hexane, ethylacetate, $90 \%$ methanol and water, respectively. The antileishmania activity was concentrated in the $90 \%$ methanol fraction. Two grams of this fraction was subjected to silica gel-column chromatography using mixtures of hexane-ethylacetate-methanol of increasing polarities. Ten fractions (F1-F10) were obtained and evaluated for biological activity. The most active fractions, F4 (50 mg) and F6 (231 mg), were finally purified by recrystal- lization in ethylacetate to afford isoplumericin (18 mg, 0.007\% yield) and in methanol for plumericin ( $70 \mathrm{mg}, 0.026 \%$ yield), respectively. Structures of isolated compounds were identified by nuclear magnetic resonance (Bruker AC300) using ${ }^{1} \mathrm{H}$ NMR (300.13 MHz), ${ }^{13} \mathrm{C}$ NMR (75.47 MHz), 2D NMR analysis, and by comparison of spectral data with those available in the literature (Abdel-Kader et al., 1997). $\mathrm{CDCl}_{3}$ was used as solvent for both compounds. For the X-ray crystallographic analysis, all data were collected at low temperatures $(173 \mathrm{~K})$ on a Bruker-AXS CCD-1000 diffractometer with Mo $\mathrm{K} \alpha$ radiation $(\lambda=0.71073 \AA)$.

\subsection{Parasites and cultures}

A cloned line of Leishmania amazonensis (strain MHOM/BR/76/LTB-012) was used in all experiments. Axenically grown amastigote forms of Leishmania amazonensis were maintained by weekly subpassages in MAA/20 medium (Sereno and Lemesre, 1997a) at $32 \pm 1{ }^{\circ} \mathrm{C}$ with $5 \%$ $\mathrm{CO}_{2}$ in $25 \mathrm{~cm}^{2}$ tissue culture flasks. Promastigote forms of Leishmania amazonensis were maintained at $25 \pm 1{ }^{\circ} \mathrm{C}$ by weekly subpassages in RPMI 1640 medium with $25 \mathrm{mM}$ HEPES and $2 \mathrm{mM} \mathrm{NaHCO}_{3}$ (pH 7.2), supplemented with $20 \%$ heat-inactivated foetal bovine serum.

\subsection{In vitro activity on amastigotes and promastigotes}

All experiments were performed in triplicate. The in vitro leishmanicidal activity of plant extracts were determined in the axenic cultures of amastigotes and promastigotes forms of Leishmania amazonensis. To estimate the 50\% inhibitory concentration $\left(\mathrm{IC}_{50}\right)$ of the extracts, the 3-(4,5-dimethylthiazol2-yl)-2,5-diphenyltetrazolium bromide (MTT) micromethod was used as previously described (Sereno and Lemesre, 1997b). Results were expressed as percentage reduction of parasite burden compared to the level in untreated control wells, and the $50 \%$ inhibitory concentration $\left(\mathrm{IC}_{50}\right)$ was determined from the concentration-response curves.

\subsection{Macrophages}

Peritoneal macrophages were prepared according to Sauvain et al. (1993). Non-inflammatory macrophages $\left(10^{5}\right)$ were collected from 6-week-old male BALB/c mice. The adherent cells were incubated at $37^{\circ} \mathrm{C}$ under $5 \% \mathrm{CO}_{2}$.

\subsection{Determination of toxicity to macrophages}

Appropriate dilutions of compounds were added to a part of the macrophages prepared above (Sauvain et al., 1993). The contact between drugs and macrophages alone lasted $48 \mathrm{~h}$ at $37{ }^{\circ} \mathrm{C}$ under $5 \% \mathrm{CO}_{2}$. The percentage of live macrophages was determined microscopically by means of the trypan blue dye exclusion test and the $\mathrm{IC}_{50}$ was determined by the same method as for amastigotes. 


\subsection{Infection of macrophages by amastigotes}

To assess intracellular antileismanial activity, medium in the wells containing the macrophages was replaced by the suspension of amastigotes using an infection ratio of $7 / 1$ amastigotes/macrophages according to Sauvain et al. (1993). Twelve hours after infection, a solution of the compounds to be tested was added to the cultures at various concentrations and maintained at $37^{\circ} \mathrm{C}$ under $5 \% \mathrm{CO}_{2}$ for another $48 \mathrm{~h}$. Plates were fixed with methanol and stained with $10 \%$ Giemsa stain. The percentage of infected macrophages was determined microscopically at 100 times magnification. The results were statistically analyzed by the ANOVA test, using the statistics for Windows program $(P<0.05)$.

\subsection{Cell cytotoxicity bioassays}

Cytotoxicity of the compounds was determined using BALB/3T3 (non-tumorogenic, BALB/c mouse embryo cells) and Vero (African green monkey kidney cells) cells. Briefly, growth inhibition was evaluated by preparing serial dilutions of each compound and incubating the cells in 96-well plates in the presence or absence of these compounds for $48 \mathrm{~h}$ at $37^{\circ} \mathrm{C}$. Appropriate solvent controls were tested for comparison. The percent inhibition of cell growth relative to control was evaluated calorimetrically using a sulforhodamine B dye according to a published procedure (Skehan et al., 1990) in comparison to control. The $\mathrm{IC}_{50}$ value was defined as the concentration of test sample resulting in a 50\% reduction of absorbance as compared with untreated controls that received a serial dilution of the solvent in which the test samples were dissolved, and was determined by linear regression analysis.

\section{Results and discussion}

Table 1 summarizes the ethnobotanical data of the seven plant species selected for this study (Lacaze and Alexiades, 1995; Mejia and Rengifo, 2000; Pinedo and Rengifo, 1997; Vasquez, 2005) and shows the results of the screening against axenic amastigote and promastigote stages in vitro. The most active plant extract $\left(\mathrm{IC}_{50}=5 \mu \mathrm{g} / \mathrm{ml}\right.$ ) on the amastigote model was the ethanol extract obtained from the Himatanthus sucuuba barks.

Table 1

Ethnobotanical information of the plants collected in the Department of Madre de Dios and results of the antileishmanial screening using promastigotes and axenic amastigotes of Leishmania amazonensis

\begin{tabular}{|c|c|c|c|c|c|}
\hline $\begin{array}{l}\text { Species (family, vernacular name, } \\
\text { voucher number) }\end{array}$ & $\begin{array}{l}\text { Traditional use reported } \\
\text { in the literature }\end{array}$ & $\begin{array}{l}\text { Place and date of } \\
\text { collection }\end{array}$ & $\begin{array}{l}\text { Preparation of the plants used } \\
\text { by the informants against } \\
\text { leishmaniasis ulcers }\end{array}$ & $\begin{array}{l}\mathrm{IC}_{50}(\mu \mathrm{g} / \mathrm{ml}) \\
\text { amastigotes }\end{array}$ & $\begin{array}{l}\mathrm{IC}_{50}(\mu \mathrm{g} / \mathrm{ml}) \\
\text { promastigotes }\end{array}$ \\
\hline $\begin{array}{l}\text { Brunfelsia grandiflora D. Don } \\
\text { ssp. Shulttessi Plow. } \\
\text { (Solanaceae Chiric sanango } \\
\text { PROCOMD-004-001/2005) }\end{array}$ & $\begin{array}{l}\text { Leishmaniasis (Mejia } \\
\text { and Rengifo, 2000) }\end{array}$ & $\begin{array}{l}\text { Community of } \\
\text { Planchón, road between } \\
\text { Puerto Maldonado and } \\
\text { Iñapari, } 38 \mathrm{~km} . \\
\text { February } 2005\end{array}$ & $\begin{array}{l}\text { The powder of the bark is } \\
\text { applied directly on the } \\
\text { affected area }\end{array}$ & $>100$ & $>100$ \\
\hline $\begin{array}{l}\text { Capirona decorticans Spruce, } \\
\text { Rubiaceae, Capirona de altura, } \\
\text { PROCOMD-005-001/2005 }\end{array}$ & $\begin{array}{l}\text { Warts, infected wounds, } \\
\text { mycosis, scabies } \\
\text { (Pinedo and Rengifo, } \\
\text { 1997) }\end{array}$ & $\begin{array}{l}\text { Community of } \\
\text { Planchón, road between } \\
\text { Puerto Maldonado and } \\
\text { Iñapari, } 38 \mathrm{~km} . \\
\text { February } 2005\end{array}$ & $\begin{array}{l}\text { The bark is rasped and } \\
\text { applied as a poultice on the } \\
\text { affected area. The bark juice } \\
\text { is also poured into the ulcer }\end{array}$ & $>100$ & $>100$ \\
\hline $\begin{array}{l}\text { Cyathea sp., Cyatheaceae, Sano } \\
\text { sano, } \\
\text { PROCOMD-006-001/2005 }\end{array}$ & $\begin{array}{l}\text { Wounds (Lacaze and } \\
\text { Alexiades, 1995) }\end{array}$ & $\begin{array}{l}\text { Community of } \\
\text { Planchón, road between } \\
\text { Puerto Maldonado and } \\
\text { Iñapari, } 38 \mathrm{~km} . \\
\text { February } 2005\end{array}$ & $\begin{array}{l}\text { The powder of the bark is } \\
\text { applied directly on the } \\
\text { affected area }\end{array}$ & $>100$ & $>100$ \\
\hline $\begin{array}{l}\text { Dracontium loretense K. Krause, } \\
\text { Araceae, Jergón sacha, } \\
\text { PROCOMD-002-001/2005 }\end{array}$ & $\begin{array}{l}\text { Leishmaniasis } \\
\text { (Vasquez, 2005) }\end{array}$ & $\begin{array}{l}\text { Community of } \\
\text { Sudadero, road between } \\
\text { Puerto Maldonado and } \\
\text { Iñapari, } 21 \mathrm{~km} . \\
\text { February } 2005\end{array}$ & $\begin{array}{l}\text { The powder of sun-dried } \\
\text { tubers is sieved and applied } \\
\text { on the ulcer four times a day } \\
\text { until healing }\end{array}$ & 60 & $>100$ \\
\hline $\begin{array}{l}\text { Himatanthus sucuuba (Spruce ex } \\
\text { Muell. Arg.) Woodson, } \\
\text { Apocynaceae, Bellaco caspi, } \\
\text { PROCOMD-008-002/2005 }\end{array}$ & $\begin{array}{l}\text { Herpes and wounds } \\
\text { (Mejia and Rengifo, } \\
\text { 2000; Villegas et } \\
\text { al.,1997) }\end{array}$ & $\begin{array}{l}\text { Community of } \\
\text { Pacahuara, Near from } \\
\text { Iberia, February } 2005\end{array}$ & $\begin{array}{l}\text { The fresh bark and latex are } \\
\text { applied directly on the } \\
\text { affected area }\end{array}$ & 5 & 20 \\
\hline $\begin{array}{l}\text { Paullinia bracteosa Radlk., } \\
\text { Sapindaceae, Abuta colorada, } \\
\text { PROCOMD-001-003/2005 }\end{array}$ & $\begin{array}{l}\text { Leishmaniasis, wounds } \\
\text { (Lacaze and Alexiades, } \\
\text { 1995; Vasquez, 2005) }\end{array}$ & $\begin{array}{l}\text { Community of Bello } \\
\text { Horizonte, road } \\
\text { between Puerto } \\
\text { Maldonado and Iñapari, } \\
12 \text { km. February } 2005\end{array}$ & $\begin{array}{l}\text { The powder of the bark is } \\
\text { applied on the ulcer }\end{array}$ & 60 & $>100$ \\
\hline $\begin{array}{l}\text { Zamia sp., Cycadaceae, } \\
\text { Zanahoria del monte, } \\
\text { PROCOMD-009-001/2005 }\end{array}$ & $\begin{array}{l}\text { Leishmaniasis, } \\
\text { cicatrization. (Mejia } \\
\text { and Rengifo, 2000; } \\
\text { Vasquez, 2005) }\end{array}$ & $\begin{array}{l}\text { Community of } \\
\text { Pacahuara, near Iberia, } \\
\text { February } 2005\end{array}$ & $\begin{array}{l}\text { The rhizome is crushed and } \\
\text { the obtained juice is poured } \\
\text { into the affected area }\end{array}$ & $>100$ & $>100$ \\
\hline
\end{tabular}


Table 2

In vitro activities of plumericin (1), isoplumericin (2) and Amphotericin B (3) against Leishmania models and cytotoxicity assays of 1 and 2 against 3 T3 and vero cells

\begin{tabular}{|c|c|c|c|c|}
\hline \multirow{2}{*}{$\begin{array}{l}\text { Activities on axenic amastigotes of } \\
\text { Leishmania amazonensis }\left(\mathrm{IC}_{50}\right)\end{array}$} & \multirow{2}{*}{$\begin{array}{l}\text { Activity on macrophages infected } \\
\text { with Leishmania amazonensis }\left(\mathrm{IC}_{50}\right)\end{array}$} & \multirow{2}{*}{$\begin{array}{l}\text { Toxicity on mice peritoneal } \\
\text { macrophages }\left(\mathrm{IC}_{50}\right)\end{array}$} & \multicolumn{2}{|c|}{ Cytotoxicity assays $\left(\mathrm{IC}_{50}\right)$} \\
\hline & & & $3 \mathrm{~T} 3$ & VERO \\
\hline (1) $0.21 \mu \mathrm{M}$ & (1) $0.9 \mu \mathrm{M}$ & (1) $1.86 \mu \mathrm{M}$ & (1) $2.00 \mu \mathrm{M}$ & (1) $1.72 \mu \mathrm{M}$ \\
\hline (2) $0.28 \mu \mathrm{M}$ & (2) NA $(*)$ & (2) $1.86 \mu \mathrm{M}$ & (2) $1.10 \mu \mathrm{M}$ & (2) $1.03 \mu \mathrm{M}$ \\
\hline (3) $0.52 \mu \mathrm{M}$ & (3) $1 \mu \mathrm{M}$ & Amphotericin B $>10 \mu \mathrm{M}$ & & \\
\hline
\end{tabular}

NA*: not available. Isoplumericin tested concentrations affected macrophages.

The barks also showed a moderate activity on a promastigote stage. Himatanthus sucuuba, a well-known medicinal plant from the Peruvian Amazon, had been previously reported as inactive against another protozoan parasite, Plasmodium falciparum (Kvist et al., 2006). On the other hand, in our plant extracts screening against axenic amastigotes of Leishmania amazonensis (one of the etiologic species of cutaneous leishmaniasis in the Amazon region), the bark of Himatanthus sucuuba showed the highest direct activity against the intracellular form of the parasite. According to this result, no significant wound-healing activity had been detected in Himatanthus sucuuba in a previous work about plant preparations used by traditional medicine practitioners in Peru as wound-healing agents (Villegas et al., 1997). Bio-guided fractionation of the stem bark from Himatanthus sucuuba using axenic amastigotes resulted in the isolation of two known spirolactone iridoids: plumericin and isoplumericin. The structures of the compounds have been confirmed by means of X-ray crystallography (Fig. 1). Both compounds show a strong activity against Leishmania amazonensis axenic amastigotes as shown in Table 2. The two compounds evaluated for their cytotoxicity on mice peritoneal macrophages and on tumoral cells have shown less toxicity than in their activity on Leishmania amastigotes (Table 2). In the case of the tumoral assays isoplumericin is more toxic than plumericin. Plumericin and its isomer were evaluated on Leishmania amazonensis in vitro

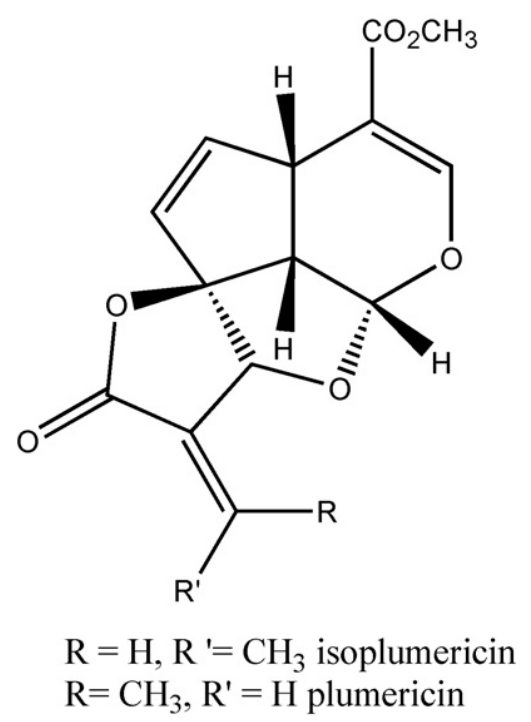

Fig. 1. Structure of plumericin and isoplumericin. infected macrophages. Isoplumericin showed a toxicity against infected macrophages which did not allow an evaluation of its activity against intracellular amastigotes. Plumericin caused a reduction of the macrophage infection similar to Amphotericin $\mathrm{B}$, the drug used more frequently when patients do not respond to antimonials, the first line chemotherapy $\left(\mathrm{IC}_{50}\right.$ of $0.9 \mu \mathrm{M}$ for plumericin and of $1 \mu \mathrm{M}$ for Amphotericin B). This difference between the effects of the two isomers on infected macrophages should be of great interest, since the radical group orientation influences the antiparasitic activity of some compounds (Montero-Torres et al., 2005). As far as we know this is the first time that antileishmanial activity is demonstrated for these types of iridoids. This kind of spirolactone iridoid is not so commonly found in nature. Only around 10 structurally related compounds have been isolated from the genera Himatanthus, Plumeria and Allamanda (Abdel-Kader et al., 1997). The results of our work indicate that it would be very interesting to isolate or synthesize structurally related compounds (Trost et al., 1986) in order to establish structure-antileishmania activity relationships.

\section{Acknowledgments}

The authors gratefully acknowledge the financial assistance of CONCYTEC from Peru and DSF-IRD (JEAI) from France. We express our gratitude to patients with leishmaniasis who were willing to share their knowledge about medicinal plants.

\section{References}

Abdel-Kader, M.S., Wisse, J., Evans, R., van der Werff, H., Kingston, D.G., 1997. Bioactive iridoids and a new lignan from Allamanda cathartica and Himatanthus fallax from the Suriname rainforest. Journal of Natural Products 60, 1294-1297.

Camacho, M.R., Phillipson, J.D., Croft, S.L., Solis, P.N., Marshall, S.J., Ghazanfar, S.A., 2003. Screening of plant extracts for antiprotozoal and cytotoxic activities. Journal of Ethnopharmacology 89, 185-191.

Chan-Bacab, M.J., Peña-Rodriguez, L.M., 2001. Plant natural products with leishmanicidal activity. Natural Product Reports 18, 674-688.

Davis, A.J., Murray, H.W., Handman, E., 2004. Drugs against leishmaniasis: a synergy of technology and partnerships. Trends in Parasitology 20, 73-76.

de Carvalho, P.B., Ferreira, E.I., 2001. Leishmaniasis phytotherapy. Nature's leadership against an ancient disease. Fitoterapia 72, 599-618.

Dedet, J.-P., Pradinaud, R., Gay, F., 1989. Epidemiological aspects of human cutaneous leishmaniasis in French Guiana. Transactions of the Royal Society of Tropical Medicine and Hygiene 83, 616-620.

Fournet, A., Barrios, A.A., Muñoz, V., 1994. Leishmanicidal and trypanocidal activities of Bolivian medicinal plants. Journal of Ethnopharmacology 41, 19-37. 
Kvist, L.P., Christensen, S.B., Rasmussen, H.B., Mejia, K., Gonzalez, A., 2006. Identification and evaluation of Peruvian plants used to treat malaria and leishmaniasis. Journal of Ethnopharmacology 106, 390402.

Lacaze, D., Alexiades, M., 1995. Salud para todos: Plantas Medicinales y Salud Iindígena en la Cuenca Delrío Madre de Dios. FENAMAD-CBC, Puerto Maldonado, p. 287.

Lucas, C.M., Franke, E.D., Cachay, M.I., Tejada, A., Cruz, M.E., Kreutzer, R.D., Barker, D.C., McCann, S.H., Watts, D.M., 1998. Geographic distribution and clinical description of leishmaniasis cases in Peru. American Journal of Tropical Medicine and Hygiene 59, 312-317.

Mejia, K., Rengifo, E., 2000. Plantas Medicinales de uso Popular en la Amazonía Peruana. Agencia Española de Cooperación Internacional (AECI) and IIAPIquitos, Lima, p. 235.

Montero-Torres, A., Vega, M.C., Marrero-Ponce, Y., Rolon, M., Gomez-Barrio, A., Escario, J.A., Aran, V.J., Martinez-Fernandez, A.R., Meneses-Marcel, A., 2005. A novel non-stochastic quadratic fingerprints-based approach for the 'in silico' discovery of new antitrypanosomal compounds. Bioorganic Medicinal Chemistry 13, 6264-6275.

Muzitano, M.F., Cruz, E.A., de Almeida, A.P., Da Silva, S.A., Kaiser, C.R., Guette, C., Rossi-Bergmann, B., Costa, S.S., 2006. Quercitrin: an antileishmanial flavonoid glycoside from Kalanchoe pinnata. Planta Medica 72 81-83.

Pinedo, P.M., Rengifo, S.E., 1997. Plantas Medicinales de la Amazonía Peruana Estudio de su uso y Cultivo. Instituto de Investigaciones de la Amazonía Peruana (IIAP), Iquitos, p. 304.

Rocha, L.G., Almeida, J.R.G.S., Macedo, R.O., Barbosa-Filho, J.M., 2005. A review of natural products with antileishmanial activity. Phytomedicine 12, 514-535.
Sauvain, M., Dedet, J.P., Kunesch, N., Poisson, J., Gayral, P., Gantier, J.C., Kunesch, G., 1993. In vitro and in vivo leishmanicidal activities of natural and synthethic quinoids. Phytotherapy Research 7, 167-171.

Sereno, D., Lemesre, J.L., 1997a. Axenically cultured amastigote forms as an in vitro model for investigation of antileishmanial agents. Antimicrobial Agents and Chemotherapy 41, 972-976.

Sereno, D., Lemesre, J.L., 1997b. Use of an enzymatic micromethod to quantify amastigote stage of Leishmania amazonensis in vitro. Parasitology Research $83,401-403$.

Skehan, P., Storeng, R., Scudiero, D., Monks, A., McMahon, J., Vistica, D., Warren, J., Bokesch, H., Kenney, S., Boyd, M., 1990. New colorimetric cytotoxicity assay for anticancer-drug screening. Journal of National Cancer Institute 82, 1107-1112.

Trost, B.M., Mao, M.K.T., Balkovec, J.M., Bulhmayer, P., 1986. A total synthesis of plumericin, Allamcin, and Allamandin. 1. Basic strategy. Journal of the American Chemical Society 108, 4965-4973.

Vasquez, Z.T., 2005. Sistematización de Plantas Medicinales que se Utilizan Tradicionalmente en Leishmania en la Región Madre de Dios. Instituto de Investigaciones de la Amazonía Peruana (IIAP), Iquitos, p. 14.

Villegas, L.F., Fernandez, I.D., Maldonado, H., Torres, R., Zavaleta, A., Vaisberg, A.J., Hammond, G.B., 1997. Evaluation of the wound-healing activity of selected traditional medicinal plants from Peru. Journal of Ethnopharmacology 55, 193-200.

Walton, B.C., 1987. American cutaneous and mucocutaneous leishmaniasis. In: Peters, W., Killick-Kendrick, R. (Eds.), The Leishmaniases in Biology and Medicine, vol. 2. Academic Press, London, pp. 637-664.

Weniger, B., Robledo, S., Arango, G.J., Deharo, E., Aragon, R., Muñoz, V., Callapa, J., Lobstein, A., Anton, R., 2001. Antiprotozoal activities of Colombian plants. Journal of Ethnopharmacology 78, 193-200. 